\title{
PENGARUH PENDAPATAN ASLI DAERAH (PAD), DANA ALOKASI UMUM (DAU), DAN DANA ALOKASI KHUSUS (DAK) FISIK TERHADAP PEMBANGUNAN MANUSIA DI PROVINSI SUMATERA UTARA (PERIODE 2016 - 2018)
}

\author{
Tri Asmeli Sembiring \\ Direktorat Jenderal Perbendaaraan \\ Alamat Korespondensi: triasmelihhi@gmail.com
}

\begin{abstract}
The goal of fiscal decentralization is to equalize the development for every states in a country, which includes economic and human development. By the decentralization policy, the state can be more independent to manage and develop their resources. Each State can use their Own Revenue as a main income in their developement budget. Nevertheless, the decentralization policy has some impacts, which are: it makes inequality among the states, because every state has different capacity of natural resources, human resources, geographical characters, \& culture. To prevent the inequality and help states to fund their development, the central government channels the Balance Fund, such as the General Alocation Fund and the Physical Special Alocation Fund. The Human Development Index is one of indicator to quantify human development and quantify government's success on its job. As a prospect, the states may increase allocation for human development projects by managing its State Own Revenue, General Alocation Fund, Physical Special Alocation Fund.
\end{abstract}

\section{KATA KUNCI:}

Pendapatan Asli Daerah (PAD), Dana Alokasi Umum (DAU), Dana Alokasi Khusus (DAK) Fisik, Indeks Pembangunan Manusia (IPM), Desentralisasi

\begin{abstract}
ABSTRAK
Seringnya terjadi bencana alam di Indonesia membuat pemerintah membutuhkan biaya yang tidak sedikit saat Sasaran yang hendak dicapai dari pelaksanaan desentralisasi fiskal adalah memeratakan pembangunan, baik itu pembangunan ekonomi dan juga pembangunan manusia. Melalui desentralisasi, daerah menjadi lebih leluasa dalam mengelola dan mengembangkan potensinya. Pemerintah daerah menggunakan Pendapatan Asli Daerah (PAD) sebagai sumber dalam membiayai pembangunan daerahnya. Namun demikian, desentralisasi fiskal juga memiliki dampak yaitu ketimpangan antardaerah, karena daerah memiliki potensi sumber daya alam, sumber daya manusia, karakter, budaya, geografis, dan topografi yang berbeda-beda. Dalam mencegah ketimpangan serta membantu daerah untuk membiayai pembangunannya, pemerintah pusat menyalurkan dana perimbangan, seperti Dana Alokasi Umum (DAU) dan Dana Alokasi Khusus (DAK) Fisik. Indeks Pembangunan Manusia (IPM) merupakan salah satu indikator dalam mengukur keberhasilan pembangunan manusia di suatu wilayah dan juga mengukur keberhasilan pemerintah dalam menjalankan fungsinya. Diharapkan dengan pengelolaan PAD, DAU, dan DAK Fisik yang baik maka pembangunan manusia di suatu wilayah dapat meningkat. Penelitian ini bertujuan untuk menganalisis pengaruh PAD, DAU, dan DAK Fisik terhadap pembangunan manusia dengan kabupaten/kota di Sumatera Utara menjadi objek penelitian selama kurun waktu 2016 2018. Metode penelitian yang digunakan adalah regresi data panel. Hasil penelitian menunjukkan PAD, DAU, dan DAK Fisik secara simultan berpengaruh signifikan terhadap pembangunan manusia. Secara parsial PAD memiliki pengaruh signifikan terhadap pembangunan manusia sementara DAU dan DAK Fisik tidak memiliki pengaruh signifikan terhadap pembangunan manusia.
\end{abstract}

\section{KLASIFIKASI JEL:}

H75

CARA MENGUTIP:

Sembiring, T. A. (2020). Pengaruh pendapatan asli daerah (pad), dana alokasi umum (dau), dan dana alokasi khusus (dak) fisik terhadap pembangunan manusia di Provinsi Sumatera Utara (periode 2016 - 2018. Indonesian Treasury Review: Jurnal Perbendaharaan, Keuangan Negara dan Kebijakan Publik, 5(1), 77-92. 
PENGARUH PENDAPATAN ASLI DAERAH (PAD),

\section{PENDAHULUAN}

Undang-Undang Nomor 32 Tahun 2004 tentang Pemerintahan Daerah menjadi dasar penyelenggaraan pemerintah daerah yang merupakan bagian dari desentralisasi pemerintah pusat. Dengan Undang-Undang tersebut pemerintah daerah memiliki kewenangan untuk menjalankan tata kelola pemerintahan dengan lebih bebas, mandiri, serta campur tangan pemerintah pusat yang lebih minim. Pemerintah daerah tentu lebih mengenal potensi-potensinya sendiri. Walaupun desentralisasi fiskal membuat peran pemerintah pusat kepada daerah menjadi terbatas, sasaran yang ingin dicapai tetap sama, yaitu peningkatan kesejahteraan masyarakat dan pembangunan manusia.

Salah satu sumber pendapatan daerah dalam membiayai pembangunan adalah Pendapatan Asli Daerah (PAD). Desentralisasi fiskal juga memiliki dampak yaitu ketimpangan antardaerah, karena daerah memiliki potensi sumber daya alam, sumber daya manusia, karakter, budaya, geografis, dan topografi yang berbeda-beda.

Dalam mencegah ketimpangan serta membantu daerah dalam membiayai pembangunannya pemerintah pusat menyalurkan dana perimbangan yang merupakan dana yang bersumber dari pendapatan APBN yang dialokasikan kepada daerah untuk mendanai kebutuhan daerah dalam rangka pelaksanaan desentralisasi. Salah satu komponen Dana Perimbangan adalah Dana Alokasi Umum (DAU) yang bertujuan untuk pemerataan kemampuan keuangan antardaerah untuk mendanai kebutuhan daerah. Selain DAU pemerintah pusat juga menyalurkan Dana Alokasi Khusus (DAK) Fisik dengan tujuan meningkatkan akselerasi percepatan pembangunan di daerah-daerah dan juga desa-desa agar pemerataan pembangunan dapat terlaksana. Apabila penggunaan dana-dana tersebut dilakukan dengan tepat sasaran dan maksimal maka pembangunan manusia di suatu daerah dapat terdorong, sesuai dengan salah satu tujuan desentralisasi fiskal yaitu meningkatkan dan memeratakan pembangunan manusia di berbagai daerah.

Derajat Otonomi Fiskal (DOF) merupakan perbandingan antar jumlah Pendapatan Asli Daerah dengan total penerimaan daerah (Mahmudi, 2010). Derajat tersebut menunjukkan kontribusi PAD terhadap total penerimaan daerah. Semakin tinggi kontribusi PAD maka semakin tinggi kemampuan pemerintah daerah dalam menyelenggarakan desentralisasi. Daerah semestinya tidak mengandalkan dana transfer sebagai sumber dana utama dalam pelaksanaan pembangunan dan pelayanan kepada masyarakat, melainkan menggunakan PAD.

Gambar 1.1 IPM Kabupaten/Kota di Sumatera Utara Periode 2015 - 2018

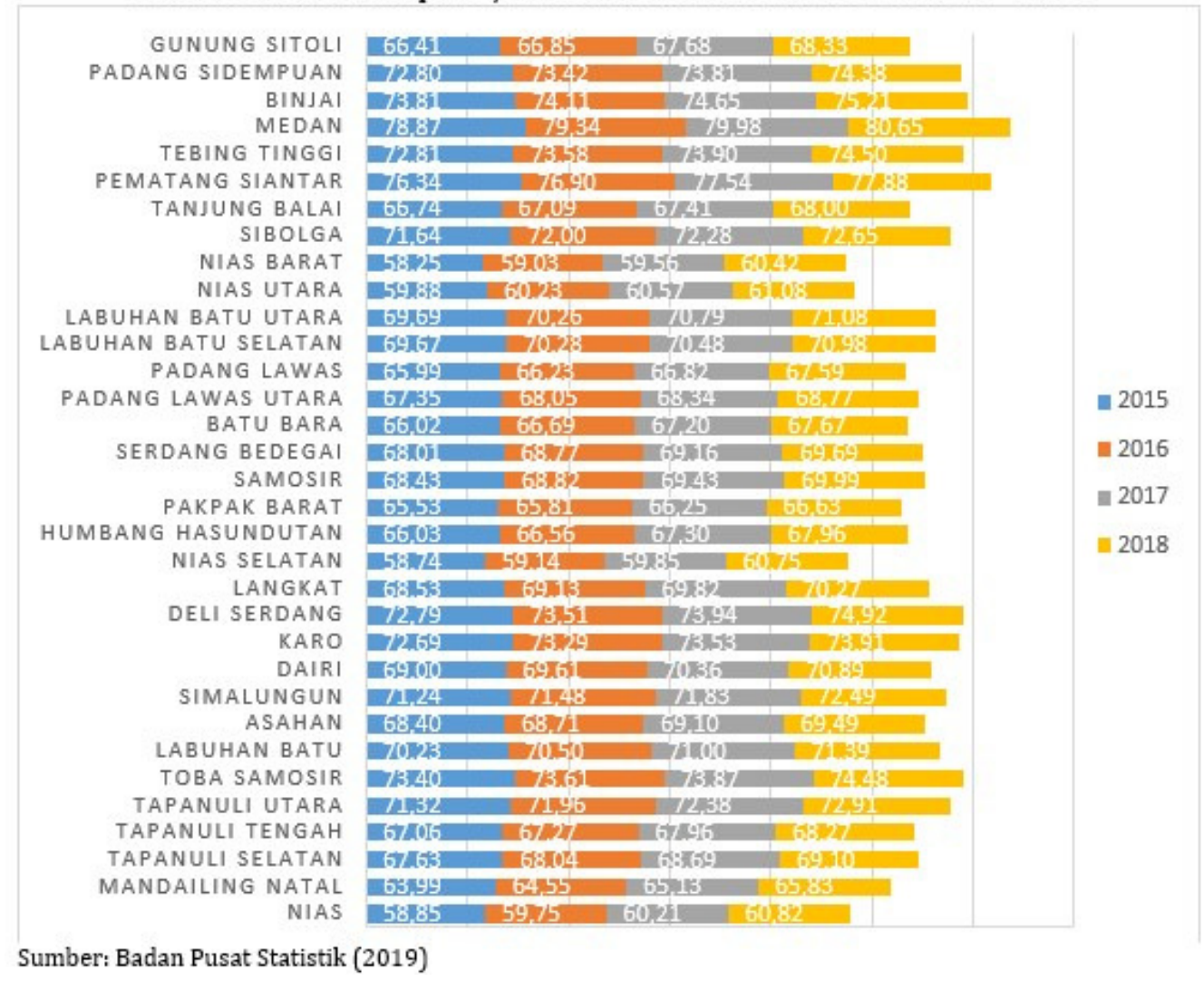


Provinsi Sumatera Utara merupakan salah satu provinsi yang awalnya memiliki IPM di atas rata-rata nasional hingga kemudian menjadi di bawah rata-rata IPM nasional. Hal ini disebabkan oleh pertumbuhan IPM nasional yang lebih tinggi dibandingkan dengan pertumbuhan IPM Sumatera Utara. IPM Sumatera Utara yang setiap tahun mengalami kenaikan, tidak serta merta berkorelasi pada penambahan jumlah kabupaten/kota yang berada di atas angka IPM Sumatera Utara. Pada tahun 2015 ada 15 kabupaten/kota yang IPM-nya di atas IPM Sumatera Utara. Di tahun berikutnya jumlah kabupaten/kota yang IPM-nya di atas rata-rata IPM provinsi berkurang menjadi 14 seiring dengan meningkatnya IPM provinsi. Di tahun 2017 pun terjadi hal yang sama, jumlah kabupaten/kota yang IPM-nya di atas angka IPM provinsi berkurang menjadi 13 kabupaten/kota. Artinya hingga tahun 2017 lebih dari setengah kabupaten/kota di Sumatera Utara memiliki IPM di bawah rata-rata IPM provinsi.

\section{LANDASAN TEORI}

\subsection{Pembangunan Manusia}

Amartya Sen (1999) merupakan pelopor pendekatan pembangunan manusia dalam ilmu ekonomi pembangunan dalam konsep Human Capabilities Approach. Pada konsep ini kemampuan manusia ditekankan sebagai bagian penting dalam pembangunan. Konsep tersebut juga ditegaskan Mahbub Ul Haq (1999) bahwa manusia adalah inti dari gagasan pembangunan. Pembangunan manusia adalah perluasan kebebasan nyata yang dinikmati oleh manusia. Pembangunan manusia juga merupakan suatu proses untuk memperbesar pilihan-pilihan bagi manusia atau a process of enlarging people's choices (UNDP, 1996). Memperbesar pilihanpilihan tersebut dapat diartikan sebagai kondisi hidup layak yang memungkinkan manusia memperoleh akses untuk mendapatkan pengetahuan, pendidikan, dan akses terhadap sumber daya yang dibutuhkan untuk hidup layak.

Ada dua pendekatan utama yang digunakan dalam melihat pembangunan manusia (Ramirez, Ranis, \& Stewart, 1997). Pendekatan yang pertama menekankan pada standar kelayakan kebutuhan dasar atau Basic Needs Approach. Pada pendekatan ini tujuan akhir dari pembangunan manusia adalah jaminan kebutuhan dasar setiap individu. Dengan terpenuhinya kebutuhan dasar tersebut, individu memiliki kesempatan untuk hidup lebih panjang dan lebih sehat, serta memiliki tingkat pengetahuan yang memadai dan menjadikan individu lebih produktif. Pendekatan yang kedua adalah Sen's Capabilities Approach yaitu pendekatan yang menekankan peningkatan kemampuan dan potensi manusia melalui konsep tentang kapabilitas yang dipopulerkan oleh Amartya Sen. Menurut pendekatan tersebut, tujuan akhir dari pembangunan manusia adalah kebebasan manusia yang semakin luas.

Empat pilar pokok pembangunan manusia kemudian dijabarkan sebagai berikut:

1. Produktivitas.

Penduduk harus meningkatkan produktivitas dan partisipasi penuh dalam proses penciptaan pendapatan dan nafkah, sehingga pembangunan ekonomi merupakan bagian dari model pembangunan manusia.

2. Pemerataan.

Penduduk memiliki kesempatan yang sama untuk mendapatkan akses terhadap sumber daya ekonomi dan sosial. Semua hambatan yang memperkecil kesempatan untuk memperoleh akses tersebut harus diminimalisasi sehingga penduduk dapat mengambil manfaat dari kesempatan yang ada dan berpartisipasi dalam kegiatan produktif yang dapat meningkatkan kualitas hidup.

3. Kesinambungan.

Akses terhadap sumber daya ekonomi dan sosial harus dijaga dan diperhatikan sisi kontinuitasnya agar nanti dapat digunakan untuk generasi-generasi yang akan datang. Semua sumber daya fisik, manusia, dan lingkungan selalu diperbaharui.

4. Pemberdayaan.

Penduduk harus berpartisipasi penuh dalam keputusan dan proses yang akan menentukan kehidupan mereka serta untuk berpartisipasi dan mengambil keputusan dalam proses pembangunan

\subsection{Indeks Pembangunan Manusia (IPM)}

IPM merupakan indeks komposit yang dihitung sebagai penyederhanaan rata-rata dari tiga indeks yang disepakati mencerminkan kemampuan dasar manusia, yang terdiri dari indeks kesehatan, indeks pendidikan, dan indeks standar hidup (UNDP, 1996).

Angka Harapan Hidup merupakan rata-rata perkiraan banyak tahun yang dapat ditempuh oleh seseorang selama hidup (BPS, 2017). Indeks Harapan Hidup juga dapat disebut jumlah tahun hidup yang diharapkan yang dapat dinikmati oleh penduduk di suatu wilayah. Angka Harapan Hidup dapat mencerminkan tingkat kesehatan suatu masyarakat dan dihitung dari hasil sensus serta survei kependudukan. Perhitungan Angka Harapan Hidup dilakukan dengan pendekatan tak langsung (indirect estimation). Batas minimum Angka Harapan Hidup menurut UNDP dan BPS adalah 20 sedangkan batas maksimumnya adalah 85.

Harapan Lama Sekolah merupakan lamanya seorang anak diharapkan bersekolah pada umur 
tertentu di masa mendatang yang dilihat dari penduduk usia tujuh tahun ke atas (BPS, 2017). Harapan Lama Sekolah dapat digunakan untuk mengetahui kondisi pembangunan sistem pendidikan di berbagai jenjang yang ditunjukkan dalam bentuk lamanya pendidikan yang diharapkand dapat dicapai oleh setiap anak.

Rata-rata Lama Sekolah adalah jumlah tahun yang digunakan oleh penduduk dalam menjalani pendidikan formal dengan asumsi kondisi normal rata-rata lama sekolah suatu wilayah tidak akan turun (BPS, 2017). Cakupan penduduk yang dihitung dalam penghitungan rata-rata lama sekolah adalah penduduk berusia 25 tahun ke atas. Batas minimum Harapan Lama Sekolah menurut UNDP dan BPS adalah 0 dengan batas maksimumnya 18. Sementara untuk Rata-rata komoditas yang digunakan dalam mengukur PPP kemudian berubah menjadi 96 komoditas. Batas minimum PNB menurut UNDP adalah USD 100 dengan batas maksimumnya USD 107.721. Sementara menurut BPS batas minimum Pengeluaran Per Kapita adalah Rp1.007.436 dan batas maksimumnya adalah Rp26.572.352.

\subsection{Perumusan Hipotesis}

\subsubsection{Bidang Kesehatan}

H1a: Pendapatan Asli Daerah memiliki pengaruh signifikan terhadap Kesehatan Masyarakat.

H1b:Dana Alokasi Umum memiliki pengaruh signifikan terhadap Kesehatan Masyarakat.

H1c: Dana Alokasi Khusus Fisik memiliki pengaruh signifikan terhadap Kesehatan Masyarakat.

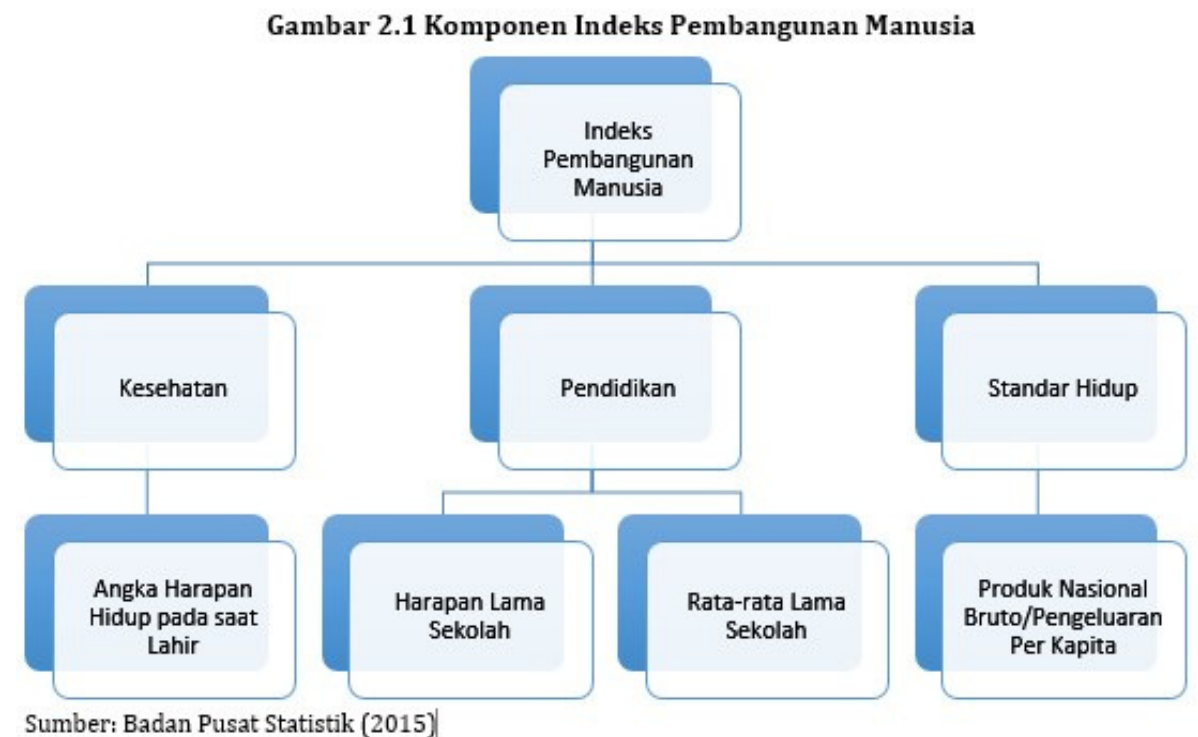

Lama Sekolah batas minimumnya adalah 0 dan batas maksimumnya adalah 15 .

Pendapatan per kapita dapat mencerminkan daya beli masyarakat. Semakin tinggi pendapatan per kapita maka semakin tinggi juga daya beli masyarakat (Mangkoesoebroto, 1991). Dengan tingginya pendapatan maka masyarakat dapat membeli berbagai macam barang/jasa dalam rangka pemenuhan kebutuhan hidupnya dengan baik. Di Indonesia variabel PNB diganti dengan Pengeluaran Perkapita sebagai variabelnya. PNB memang lebih menggambarkan kesejahteraan masyarakat dibanding dengan pengeluaran perkapita. Namun data PNB tidak tersedia di Indonesia sehingga digunakan Pengeluaran Per Kapita sebagai pengganti. Variabel Pengeluaran Per Kapita ditentukan dari nilai pengeluaran perkapita dan paritas daya beli atau Purchasing Power Parity/PPP (BPS, 2017). Rata-rata pengeluaran perkapita dibuat konstan dengan tahun dasar 2012 = 100 yang dihitung dari level provinsi hingga level kabupaten/kota. Pada metode perhitungan sebelumnya ada 27

\subsubsection{Bidang Pendidikan}

H2a: Pendapatan Asli Daerah memiliki pengaruh signifikan terhadap Pendidikan Masyarakat.

H2b:Dana Alokasi Umum memiliki pengaruh signifikan terhadap Pendidikan Masyarakat.

H2c: Dana Alokasi Khusus Fisik memiliki pengaruh signifikan terhadap Pendidikan Masyarakat.

\subsubsection{Standar Hidup}

H3a: Pendapatan Asli Daerah memiliki pengaruh signifikan terhadap Daya Beli Masyarakat.

H3b:Dana Alokasi Umum memiliki pengaruh signifikan terhadap Daya Beli Masyarakat.

H3c: Dana Alokasi Khusus Fisik memiliki pengaruh signifikan terhadap Daya Beli Masyarakat. 


\section{METODOLOGI PENELITIAN}

\subsection{Model Penelitian}

Analisis dalam penelitian ini menggunakan uji regresi data panel. Data panel merupakan gabungan antara data deret waktu atau time series dan data deret silang atau cross section (Nachrowi dan Usman, 2006). Data time series adalah data yang terdiri atas satu atau lebih variabel yang diamati pada satu unit observasi dalam kurun waktu tertentu. Data cross section adalah data yang terdiri dari satu atau lebih variabel yang diamati dalam satu waktu observasi tertentu. Model persamaan yang dibangun dari dalam penelitian ini antara lain:

$$
\begin{array}{ll}
\text { AHH } & =\alpha+\beta 1 \text { PADit }+\beta 2 \text { DAUit }+\beta 3 \text { DAKFit }+ \text { et } \\
\text { HLS } & =\alpha+\beta 4 \text { PADit }+\beta \text { DAUit }+\beta 6 \text { DAKFit }+ \text { et } \\
\text { RLS } & =\alpha+\beta \text { PADit }+\beta \text { DDAUit }+\beta \text { DAKFit }+ \text { et } \\
\text { PPK } & =\alpha+\beta 10 \text { PADit }+\beta 11 \text { DAUit }+\beta 12 \text { DAKFit } \\
& + \text { et }
\end{array}
$$

dengan keterangan:

$\begin{array}{lll}\text { AHH } & : & \text { Angka Harapan Hidup } \\ \text { HLS } & : & \text { Harapan Lama Sekolah } \\ \text { RLS } & : & \text { Rata-rata Lama Sekolah } \\ \text { PPK } & : & \text { Pengeluaran Per Kapita } \\ \text { PAD } & : & \text { Penerimaan Asli Daerah } \\ \text { DAU } & : \text { Dana Alokasi Umum } \\ \text { DAKF } & : \text { Dana Alokasi Khusus Fisik } \\ \text { i } & : \text { Kabupaten/Kota } \\ \text { t } & : \text { waktu } \\ \text { et } & : \text { error term }\end{array}$

Data panel yang digunakan di dalam penelitian ini adalah data Indeks Pembangunan Manusia (yang terdiri dari Angka Harapan Hidup, Harapan Lama Sekolah, Rata-rata Lama Sekolah, Pengeluaran Per Kapita), Pendapatan Asli Daerah, Dana Alokasi Umum, dan Dana Alokasi Khusus Fisik untuk 33 Kabupaten/Kota di Sumatera Utara sebagai data cross section selama periode tahun 2016 - 2018 sebagai data time series-nya.

\subsection{Uji Pemilihan Model}

Terdapat tiga model pendekatan yang digunakan dalam melakukan estimasi model regresi data panel (Rosadi, 2011), yaitu Common Effect, Fixed Effect Model, dan Random Effect Model. Pemilihan model yang terbaik dilakukan dengan melakukan beberapa uji, yaitu Uji Chow, Uji Hausman, dan Uji Langrange Multiplier.

Uji Chow digunakan untuk menentukan pendekatan yang akan digunakan dalam regresi data panel, yaitu antara pendekatan Common Effect atau Fixed Effect Model. Hipotesis pada Uji Chow antara lain:

H0 : menggunakan Common Effect

\section{H1 : menggunakan Fixed Effect Model}

Nilai Probabilitas F atau Chi-square yang dihasilkan dari Uji Chow akan dibandingkan dengan $\alpha$ sebesar $5 \%$ atau 0,05 . Apabila nilai Probabilitas $\mathrm{F}$ atau Chi-square $>\alpha$ maka Ho diterima atau pendekatan yang digunakan adalah Common Effect. Sebaliknya jika nilai Probabilitas F atau Chi-square $<\alpha$ maka Ho ditolak atau pendekatan yang digunakan adalah Fixed Effect Model. Bila berdasarkan Uji Chow model yang dipilih adalah Common Effect, maka uji regresi data panel dapat langsung dilakukan. Bila model yang dipilih adalah Fixed Effect Model maka akan dilanjutkan dengan melakukan Uji Hausman. Uji Hausman digunakan untuk menentukan model yang akan digunakan, yaitu antara Fixed Effect Model atau Random Effect Model.

Uji Hausman merupakan uji yang dilakukan untuk menentukan model yang akan dipakai, yaitu antara Fixed Effect Model atau Random Effect Model. Hipotesis pada Uji Hausman antara lain:

H0 : menggunakan Random Effect Model

H1 : menggunakan Fixed Effect Model

Nilai Probabilitas F atau Chi-square yang dihasilkan dari Uji Hausman akan dibandingkan dengan $\alpha$ sebesar $5 \%$ atau 0,05. Apabila nilai Probabilitas $\mathrm{F}$ atau Chi-square $>\alpha$ maka Ho diterima atau pendekatan yang digunakan adalah Random Effect Model. Sebaliknya jika nilai Probabilitas F atau Chi-square $<\alpha$ maka Ho ditolak atau pendekatan yang digunakan adalah Fixed Effect Model. Bila berdasarkan Uji Hausman model yang dipilih adalah Fixed Effect Model, maka uji regresi data panel dapat langsung dilakukan. Bila model yang dipilih adalah Random Effect Model maka akan dilanjutkan dengan melakukan Uji Langrange Multiplier. Uji ini digunakan untuk menentukan model yang akan digunakan, yaitu antara Fixed Effect Model atau Common Effect Model

Uji Langrange Multiplier merupakan uji yang dilakukan untuk menentukan model yang akan dipakai, yaitu antara Random Effect Model atau Common Effect Model. Hipotesis pada Uji Hausman antara lain:

H0 : menggunakan Common Effect Model

H1 : menggunakan Random Effect Model

Nilai Probabilitas F atau Chi-square yang dihasilkan dari Uji Langrange Multiplier akan dibandingkan dengan $\alpha$ sebesar 5\% atau 0,05. Apabila nilai Probabilitas F atau Chi-square $>\alpha$ maka Ho diterima atau pendekatan yang digunakan adalah Common Effect Model. 
PENGARUH PENDAPATAN ASLI DAERAH (PAD),

Sebaliknya jika nilai Probabilitas F atau Chi-square $<\alpha$ maka Ho ditolak atau pendekatan yang digunakan adalah Random Effect Model.

\subsection{Uji Hipotesis}

Uji hipotesis pada sebuah penelitian dapat dilakukan dengan beberapa cara, yaitu dengan Uji Koefisien Determinasi $\left(R^{2}\right)$, Uji Signifikansi Simultan (Uji F), dan Uji Signifikansi Parsial (Uji t). Uji Koefisien Determinasi dilakukan untuk mengukur kualitas dan kemampuan variabelvariabel independen dalam menjelaskan variabel dependen. Uji Signifikansi Simultan dilakukan untuk mengetahui pengaruh seluruh variabel secara bersama-sama terhadap variabel dependen. Uji Signifikansi Parsial dilakukan untuk mengetahui pengaruh variabel-variabel independen secara parsial atau terpisah terhadap variabel dependen di dalam penelitian.

\section{HASIL PENELITIAN}

Berdasarkan hasil estimasi dapat dilihat bahwa keempat persamaan menggunakan Fixed Effect Model setelah nilai Chi-square yang lebih kecil dari $\alpha$ pada Uji Chow dan Uji Hausman. Hasil uji t pada variabel DAU di keempat persamaan menunjukkan variabel-variabel memiliki hubungan negatif komponen pembangunan manusia. Demikian juga dengan variabel DAK Fisik yang memiliki pengaruh signifikan dan berhubungan negatif. Hasil uji $t$ tersebut berlawanan dengan teori yamg menyatakan DAU dan DAK Fisik disalurkan untuk meningkatkan pembangunan manusia di daerah. Variabel DAU dan DAK Fisik kemudian diregresi dengan menggunakan lag t-1 untuk mengetahui pengaruh kedua variabel-variabel tersebut di tahun berjalan dan tahun berikutnya. Hasil uji t menunjukkan bahwa dengan menggunakan lag t-1 nilai variabel DAU dan DAK Fisik yang sebelumnya memiliki tanda negatif berubah menjadi positif, artinya DAU dan DAK Fisik memiliki pengaruh di tahun

Tabel 4.1

Hasil Estimasi Penelitian

\begin{tabular}{|c|c|c|c|c|}
\hline \multirow{2}{*}{ Variabel } & \multirow{2}{*}{ Hipotesis } & \multicolumn{3}{|c|}{ Koefisien } \\
\hline & & Common Effect & Fixed Effect & Random Effect \\
\hline \multicolumn{5}{|c|}{ Model 1: Angka Harapan Hidup } \\
\hline PAD & Terima & $1,77 \mathrm{E}-06$ & $5,57 \mathrm{E}-07^{*}$ & 0,000903 \\
\hline DAU & Tolak & $1,52 \mathrm{E}-06$ & $-3,84 \mathrm{E}-06$ & $-0,000782$ \\
\hline DAK Fisik & Tolak & $-3,17 \mathrm{E}-06$ & $-8,25 \mathrm{E}-07$ & $-0,003483$ \\
\hline Adj. R-Squared & & 0,124332 & 0,995216 & 0,576408 \\
\hline Prob. F-Statistik & & 0,001339 & $0,000000^{*}$ & 0,000000 \\
\hline Uji Chow & & 0,0000 & & Fixed Effect \\
\hline Uji Hausman & & 0.0490 & & Fixed Effect \\
\hline Uji Langrange Multiplier & & & & - \\
\hline \multicolumn{5}{|c|}{ Model 2: Harapan Lama Sekolah } \\
\hline PAD & Terima & $1,12 \mathrm{E}-06$ & $5,83 \mathrm{E}-07^{*}$ & $6,27 \mathrm{E}-07$ \\
\hline DAU & Tolak & $-6,04 \mathrm{E}-07$ & $3,37 \mathrm{E}-07$ & $-2,45 \mathrm{E}-07$ \\
\hline DAK Fisik & Tolak & $-2,54 \mathrm{E}-06$ & $-7,36 \mathrm{E}-07$ & $-7,38 \mathrm{E}-07$ \\
\hline Adj. R-Squared & & 0,218342 & 0,990045 & 0,385099 \\
\hline Prob. F-Statistik & & 0,000008 & $0,000000^{*}$ & 0,000000 \\
\hline Uji Chow & & 0,0000 & & Fixed Effect \\
\hline Uji Hausman & & 0,0136 & & Fixed Effect \\
\hline Uji Langrange Multiplier & & - & & - \\
\hline \multicolumn{5}{|c|}{ Model 3:Rata-rata Lama Sekolah } \\
\hline PAD & Terima & $1,07 \mathrm{E}-06$ & $2,28 \mathrm{E}-07^{*}$ & $3,18 \mathrm{E}-07$ \\
\hline DAU & Tolak & $8,39 \mathrm{E}-07$ & $5,77 \mathrm{E}-07$ & $6,25 \mathrm{E}-07$ \\
\hline DAK Fisik & Tolak & $-7,77 \mathrm{E}-06$ & $1,76 \mathrm{E}-07$ & $-1,78 \mathrm{E}-06$ \\
\hline Adj. R-Squared & & 0,161204 & 0,998684 & 0,365933 \\
\hline Prob. F-Statistik & & 0,000191 & $0,000000^{*}$ & 0,000000 \\
\hline Uji Chow & & 0,0000 & & Fixed Effect \\
\hline Uji Hausman & & 0,0004 & & Fixed Effect \\
\hline Uji Langrange Multiplier & & - & & - \\
\hline \multicolumn{5}{|c|}{ Model 4: Pengeluaran Per Kapita } \\
\hline PAD & Terima & 0,141647 & $0,023938^{*}$ & 0,025554 \\
\hline DAU & Tolak & 0,065916 & $-0,026654$ & 0,131432 \\
\hline DAK Fisik & Tolak & $-0,006218$ & $-0,028436$ & $-0,028889$ \\
\hline Adj. R-Squared & & 0,425345 & 0,997565 & 0,607413 \\
\hline Prob. F-Statistik & & 0,000000 & $0,000000^{*}$ & 0,000000 \\
\hline Uji Chow & & 0,0000 & & Fixed Effect \\
\hline Uji Hausman & & 0,0050 & & Fixed Effect \\
\hline Uji Langrange Multiplier & & - & & - \\
\hline
\end{tabular}

Sumber: olahan Eviews; tanda $\left(^{*}\right)$ berarti berpengaruh signifikan 
berikutnya, bukan di tahun berjalan. DAU dan DAK Fisik pada tahun 2016 baru memiliki pengaruh terhadap pembangunan manusia di tahun 2017. Demikian juga variabel tersebut pada tahun 2017 baru memiliki pengaruh terhadap pembangunan manusia di tahun 2018 walaupun belum signifikan.

APBD kabupaten/kota di Sumatera Utara masih sangat bergantung pada dana transfer, baik dari pemerintah pusat atau pemerintah provinsi. Pada tahun 2017 sebanyak 83\% anggaran pendapatan daerah-daerah di Sumatera Utara berasal dari anggaran pendapatan transfer. Sedangkan pada tahun 2018 proporsi anggaran pendapatan transfer terhadap anggaran pendapatan daerah-daerah di Sumatera Utara menurun menjadi 76,1\%. Pada tahun 2017 seluruh kabupaten/kota di Sumatera Utara memiliki DOF di bawah $40 \%$ artinya tidak ada daerah di Sumatera Utara yang memiliki DOF berkategori baik. Pada tahun 2018 Medan merupakan satu-satunya kota di Sumatera Utara yang memiliki DOF berkategori baik, dengan DOF $41,11 \%$. Secara kumulatif rata-rata DOF daerah di Sumatera Utara adalah $15,91 \%$ atau berada pada kategori kurang. pembantu ada 2.045 unit dan puskesmas keliling ada 559 unit. Rasio tenaga kesehatan dengan penduduk juga mengalami peningkatan. Rasio dokter umum dengan penduduk adalah 22,15/100.000 penduduk. Rasio dokter spesialis dengan penduduk adalah 22,70/100.000 penduduk. Rasio dokter gigi dengan penduduk adalah 6,25/100.000 penduduk. Rasio perawat dengan penduduk adalah 124,05/100.000 penduduk sedangkan rasio bidan dengan penduduk adalah 118,65/100.000 penduduk.

Di bidang pendidikan hasil penelitian menunjukkan PAD memiliki pengaruh signifikan terhadap Harapan Lama Sekolah (HLS). PAD juga memiliki pengaruh signifikan terhadap Rata-rata Lama Sekolah (RLS). HLS menunjukkan kesiapan pemerintah dalam menyediakan fasilitas pendidikan kepada anak-anak yang akan bersekolah atau peluang anak untuk bersekolah. HLS juga digunakan untuk mengetahui kondisi pembangunan sistem pendidikan di berbagai jenjang mulai dari tingkat dasar hingga tingkat atas di suatu daerah. Daerah-daerah di Sumatera Utara mampu mengelola PAD dengan baik dan mampu menyediakan sistem pendidikan yang baik. Angka HLS di Sumatera Utara berada di kisaran 13 tahun atau setara dengan pendidikan Diploma I artinya pemerintah daerah di Sumatera

Tabel 4.2

Hasil Estimasi Penelitian dengan Menggunakan Lag (-1)

\begin{tabular}{lll}
\hline \multicolumn{1}{c}{ Komponen Pembangunan Manusia } & DAU $(-1)$ & DAK Fisik (-1) \\
\hline Angka Harapan Hidup & Tidak signifikan & Tidak signifikan \\
Harapan Lama Sekolah & Tidak signifikan & Tidak signifikan \\
Rata-rata Lama Sekolah & Tidak signifikan & Tidak signifikan \\
Pengeluaran Per Kapita & Tidak signifikan & Tidak signifikan \\
\hline
\end{tabular}

Sumber: ouput Eviews

\subsection{Pengaruh Pendapatan Asli Daerah terhadap Pembangunan Manusia}

Di bidang kesehatan hasil penelitian menunjukkan PAD memiliki pengaruh signifikan terhadap Angka Harapan Hidup (AHH). Daerahdaerah di Sumatera Utara mampu mengelola PAD dengan baik dan menggunakannya untuk sektor kesehatan. PAD tersebut digunakan untuk penyelenggaraan sarana dan prasarana kesehatan, serta pelayanan publik lainnya di bidang kesehatan. Pengelolaan PAD yang baik berdampak pada meningkatnya Angka Harapan Hidup penduduk di daerah-deaerah se-Sumatera Utara. Dinas Kesehatan Sumatera Utara mengatakan bahwa rasio sarana pelayanan kesehatan di Sumatera Utara mengalami peningkatan. Hingga tahun 2017 jumlah rumah sakit di Sumatera Utara ada 208 unit sedangkan jumlah puskesmas ada 571 unit dengan setiap kecamatan memiliki minimal satu puskesmas. Jumlah puskesmas telah menyediakan sistem dan fasilitas pendidikan bagi anak-anak yang hendak bersekolah hingga 13 tahun.

Angka RLS di Sumatera Utara berada di kisaran sembilan tahun atau setara dengan lulusan SMP. Hasil Susenas BPS tahun 2014 mengatakan bahwa penyebab utama anak tidak bersekolah/putus sekolah adalah tidak ada biaya $(50,15 \%)$. Penyebab yang lain adalah seperti menikah/mengurus rumah tangga $(6,42 \%)$, merasa pendidikan sudah cukup $(9,09 \%)$, memilih bekerja $(11,97 \%)$. Daerah-daerah di Sumatera Utara sudah dapat mengoptimalkan PAD dan menggunakannya untuk memberikan bantuan biaya pendidikan seperti BOS (Belanja Operasional Sekolah), BAUSKM (Bantuan Anak Usia Sekolah Keluarga Miskin), dan bantuan lainnya kepada masyarakat agar bisa terus melanjutkan pendidikannya dan tidak putus sekolah karena himpitan biaya.

Di sisi daya beli masyarakat hasil penelitian menunjukkan PAD memiliki pengaruh signifikan terhadap Pengeluaran Per Kapita. Pemerintah 
daerah mengoptimalkan PAD untuk sektor-sektor yang dapat mendorong pertumbuhan ekonomi di daerah dan peningkatan pendapatan masyarakat, seperti penyediaan lapangan kerja, industri padat karya, mendorong investasi masuk ke daerah, dan pengembangan pariwisata. Akibatnya daya beli atau konsumsi rumah tangga di daerah-daerah tidak terpengaruh oleh pengelolaan PAD.

Realisasi PAD Kabupaten/Kota di Sumatera Utara menurut data Direktorat Jenderal Perimbangan Keuangan mencapai 90,86\%. Tingginya realisasi disebabkan oleh realisasi pajak yang baik. Upaya pemerintah daerah dalam memperluas basis data pajak, layanan pembayaran pajak, dan insentif dinilai membuat masyarakat mau untuk membayar pajak. Tiga daerah yang memiliki persentase tertinggi dalam realisasi pendapatan adalah Kabupaten Nias dengan realisasi sebesar 56\%, Kabupaten Tapanuli Selatan dengan realisasi 55\%, dan Kabupaten Langkat dengan realisasi 54\%. Menurut data Direktorat Jenderal Perimbangan Keuangan juga dapat dilihat bahwa sejak tahun 2015 hingga 2018 PAD Sumatera Utara tumbuh dengan baik dan realisasinya melebih target.

\subsection{Pengaruh Dana Alokasi Umum (DAU) terhadap Pembangunan Manusia}

Hasil penelitian menunjukkan bahwa DAU tidak memiliki pengaruh signifikan terhadap sektor kesehatan, pendidikan, serta daya beli masyarakat. Faktor utama penyebabnya adalah penggunaan DAU yang tidak tepat sasaran. Pengelolaan DAU yang bersifat block grant membuat daerah bebas menggunakan DAU sesuai dengan kepentingannya. Kebanyakan daerah menggunakan DAU untuk keperluan belanja operasional, belanja gaji pegawai, dan urusan pemerintahan lainnya. Sebaliknya pemerintah daerah kurang memperhatikan pelayanan publik di bidang kesehatan dan pendidikan yang lebih dibutuhkan masyarakat.

Proporsi belanja APBD daerah-daerah di Sumatera Utara lebih fokus pada belanja operasi dibandingkan dengan belanja modal. Menurut Kajian Ekonomi dan Keuangan Regional Provinsi Sumatera Utara Triwulan III 2017 alokasi belanja operasi pada APBD 2017 adalah sebesar 78\% berbanding dengan alokasi belanja modal yang hanya 21\%. Hingga triwulan III realisasi belanja modal mencapai $32,61 \%$ dari pagu. Kemudian menurut Kajian Ekonomi dan Keuangan Regional Provinsi Sumatera Utara pada bulan Agustus 2018, 79,09\% alokasi belanja APBD merupakan belanja operasi, sementara alokasi belanja modal hanya 20,74\%. Proporsi yang timpang ini menunjukkan komitmen pemerintah yang kurang dalam memberikan pelayanan kepada masyarakat. Belanja operasi hanya berfokus pada kebutuhan PNS daerah dan perangkat pemerintah lainnya, seperti keperluan gaji, tunjangan, dan honorarium. Sebaliknya alokasi belanja modal dibutuhkan untuk membangun sarana dan prasarana pelayanan kepada masyarkat. DAU tidak digunakan tepat sasaran dan tidak sesuai dengan tujuan utamanya lagi. Anggaran yang berfokus pada belanja operasi hanya dapat dinikmati sebagian pihak.

\subsection{Pengaruh Dana Alokasi Khusus (DAK) Fisik terhadap Pembangunan Manusia}

DAK Fisik tidak memiliki pengaruh signifikan terhadap bidang kesehatan, pendidikan, dan standar hidup. Penyebabnya ada dari sisi pemerintah daerah sendiri, pemerintah pusat, dan kementerian/lembaga. Dari sisi pemerintah daerah penyebabnya adalah komitmen pemerintah daerah yang kurang dalam pelaksanaan DAK Fisik. Pemerintah daerah sudah diberikan alokasi DAK Fisik namun pelaksanaannya kurang maksimal yang berdampak pada penyerapan anggaran DAK Fisik Perencanaan yang kurang matang membuat pemerintah daerah melakukan perubahan rencana kegiatan. Proses perubahan rencana tersebut cukup panjang karena harus melibatkan DPRD dan persetujuan dari pemerintah pusat. Proses yang panjang tersebut membuat pelaksanaan DAK Fisik berpotensi terlambat dan tidak selesai tepat waktu. Dari sisi pemerintah pusat faktor penyebabnya adalah ketidakpastian pemerintah pusat dalam memberikan informasi besaran alokasi DAK Fisik di tahun berikutnya. Hal ini membuat pemerintah daerah kesulitan dalam melakukan perencanaan kegiatan. Ketidakpastian besaran alokasi DAK Fisik dapat disebabkan oleh anggaran belanja dan transfer pemerintah pusat yang bergantung pada realisasi penerimaan di tahun berjalan. Dari sisi kementerian/lembaga faktor penyebabnya adalah kementerian/lembaga yang terlambat menerbitkan petunjuk teknis pelaksanaan dan penyaluran DAK Fisik. Terlambatnya petunjuk teknis terbit membuat pemerintah daerah penerima DAK Fisik kesulitan untuk mengeksekusi dana tersebut. Faktor lain yang menyebabkan pengaruh DAK Fisik tidak signifikan terhadap pembangunan manusia di daerah adalah permasalahan lelang, mulai dari gagal lelang, proses lelang yang terlambat, hingga rekanan lelang yang jauh dari lokasi daerah penerima DAK Fisik. Permasalahan lelang membuat pelaksanaan kegiatan DAK Fisik menjadi terlambat, output yang dihasilkan tidak dapat langsung digunakan, dan kerap membuat penyerapannya tidak maksimal.

\subsection{Perkembangan Pembangunan Bidang Kesehatan dan Pendidikan di Sumatera Utara}


Fasilitas-fasilitas kesehatan dan pendidikan di daerah dibangun dengan APBD. Pembiayaan kesehatan di Sumatera Utara sebagian besar bersumber dari APBD Kabupaten/Kota yaitu sebesar 73,06\% dan APBN sebesar 26,13\%. Alokasi anggaran kesehatan meningkat terus dari tahun 2013 hingga 2016 kemudian mengalami penuruan pada tahun 2017. Jumlah pukesmas perawatan dan nonperawatan tidak bertambah sejak tahun 2015 hingga 2017, yaitu 174 unit puskesmas perawatan dan 397 unit puskesmas nonperawatan (Dinas Kesehatan Provinsi Sumatera Utara, 2018). Sementara itu puskesmas pembantu dan puskesmas keliling jumlahnya tahun 2016 hingga 2017, yaitu 2.045 unit puskesmas pembantu dan 559 unit puskesmas keliling. Dinas Kesehatan Provinsi Sumatera Utara juga mengungkapkan bahwa rasio puskesmas dengan desa adalah 1:3 yang artinya di setiap tiga desa ada satu fasilitas puskesmas. Sementara itu rasio puskesmas dengan kecamatan di Sumatera Utara adalah 1,29 (444 kecamatan dengan 571 puskesmas). Menurut Direktorat Jenderal Pelayanan Kesehatan Kementerian Kesehatan dari total kabupaten/kota di Sumatera Utara sebanyak 16 daerah memiliki puskesmas yang sesuai dengan standar (108 unit) sedangkan 17 daerah lagi belum memiliki puskesmas yang standar. Kemudian jumlah kabupaten yang memiliki puskesmas yang terakreditasi sebanyak 26 daerah dengan persentase puskesmas terakreditasi 23,64\% (135 dari total 571 puskesmas).

Jumlah rumah sakit di Sumatera Utara tahun 2017 adalah 208 unit, yang terdiri dari 61 rumah sakit pemerintah dan 147 rumah sakit swasta. persentasenya 46\%. Dari total 100 unit yang sudah terakreditasi ada 23 unit rumah sakit pemerintah dan 77 lagi rumah sakit swasta. Berdasarkan data Dinas Kesehatan Provinsi Sumatera Utara juga diketahui bahwa dari sisi SDM kesehatan ada empat tenaga kesehatan yang sudah mencapai standar nasional, yaitu dokter spesialis, perawat, bidan, dan tenaga farmasi.

Provinsi Sumatera Utara memiliki persentase cakupan imunisasi dasar pada bayi sebesar $86,7 \%$, artinya sekitar $86,7 \%$ (262.146 jiwa) bayi di Sumatera Utara sudah mendapatkan imunisasi dasar. Pada tahun 2015 kabupaten/kota yang sudah mencapai $80 \%$ imunisasi dasar ada 18 dari total 33 kabupaten/kota (54,55\%). Keadaan tersebut membaik pada tahun 2016, jumlah kabupaten/kota yang sudah mencapai $80 \%$ imunisasi dasar ada 24 kabupaten/kota (72,73\%) dan pada tahun 2017 meningkat lagi menjadi 25 kabupaten/kota (75,76\%). Pemerintah daerah harus dapat meningkatkan pelayanan kesehatannya agar pada tahun-tahun berikutnya seluruh daerah di Sumatera Utara memperoleh minimal 80\% imunisasi dasar.

Jumlah sekolah mulai dari SD hingga SMA di Sumatera Utara cenderung mengalami peningkatan walaupun ada di tahun-tahun tertentu mengalami penurunan. Jumlah SMP dari tahun 2015 ke 2016 mengalami penurunan sebelum kemudian meningkat kembali di tahun 2017. Demikian juga jumlah SMA mengalami penurunan di tahun 2015 ke 2016. Jumlah kenaikan terbesar ada pada unit SD di tahun 2016 ke 2017 yaitu sebesar 121 unit.

Hingga tahun 2017 jumlah SD paling sedikit

Tabel 4.3 Jumlah Rumah Sakit dan Puskesmas di Sumatera Utara

\begin{tabular}{ccccccc}
\hline \multirow{2}{*}{ Tahun } & \multicolumn{2}{c}{ Rumah Sakit } & \multicolumn{5}{c}{ Puskesmas } \\
\cline { 2 - 7 } & Pemerintah & Swasta & Perawatan & $\begin{array}{c}\text { Non- } \\
\text { perawatan }\end{array}$ & Pembantu & Keliling \\
\hline 2013 & 61 & 146 & 170 & 400 & 1.910 & 517 \\
2014 & 60 & 146 & 176 & 394 & 1.927 & 444 \\
2015 & 63 & 140 & 174 & 397 & 1.956 & 487 \\
2016 & 63 & 140 & 174 & 397 & 2.045 & 559 \\
2017 & 61 & 147 & 174 & 397 & 2.045 & 559 \\
\hline \multicolumn{2}{l}{ Sumber: Badan Pusat Statistik Provinsi Sumatera Utara (2018) }
\end{tabular}

Dari 33 kabupaten/kota di Sumatera Utara hanya Kabupaten Nias Utara, Kabupaten Nias Barat, dan Kota Gunung Sitoli yang belum memiliki rumah sakit pemerintah. Sementara itu hingga tahun 2017 ada 18 banyak daerah yang hanya memiliki satu rumah sakit pemerintah di daerahnya atau lebih dari setengah jumlah daerah di Sumatera Utara, seperti daerah Tanjung Balai, Pematang Siantar, Tapanuli, Padang Lawas, Samosir, dan daerah lain.

Fasilitas rumah sakit masih terpusat di Medan yang memiliki delapan rumah sakit pemerintah dan 64 rumah sakit swasta. Berdasarkan Direktorat Jenderal Pelayanan Kesehatan Kementerian Kesehatan dari seluruh rumah sakit sebanyak 100 unit sudah terakreditasi atau ada di Kabupaten Pakpak Barat dengan 58 unit. Selisih tersebut sangat jauh jika dibandingkan dengan Medan sebagai kota dengan jumlah SD terbanyak (850 unit). Sedangkan daerah dengan jumlah SMP paling sedikit adalah Kota Sibolga yaitu 15 unit, sangat jauh dibandingkan dengan Medan yang memiliki 380 unit SMP. Pakpak Barat juga merupakan daerah dengan jumlah SMA paling sedikit, yaitu 5 (lima) unit. Medan, adalah kota dengan SMA paling banyak, memiliki 213 unit SMA.

Menurut data Badan Kepegawaian Negara (BKN) pada tahun 2016 rasio antara murid dan guru SD di Sumatera Utara adalah 1:16 dengan rasio nasional 1:15. Pada tingkat SMP rasio antara murid dan guru adalah 1:14 dengan rasio nasional 
1:13. Sedangkan pada tingkat SMA rasio antara murid dan guru adalah 1:12 dan sama dengan rasio nasional. Pemerintah daerah perlu memperhatikan rekrutmen dan distribusi guru terutama di tingkat SD dan SMP agar rasio antara guru dan murid bisa ideal.

Data Neraca Pendidikan Daerah Kementerian Pendidikan dan Kebudayaan menunjukkan daerah-daerah di Sumatera Utara tahun 2018 belum semuanya memprioritaskan pendidikan. Hal tersebut dapat ditunjukkan dari persentase Anggaran Pendidikan tanpa Transfer Daerah, artinya APBD yang belum mendapat alokasi dana transfer dari pemerintah pusat. Daerah yang mengalokasikan anggaran pendidikan terbesar dari APBD tanpa transfer daerah adalah Kabupaten Mandailing Natal dengan 17,54\% kemudian Deli Serdang dengan 16,78\%. Medan sebagai ibukota provinsi mengalokasikan 6,79\% anggarannya untuk pendidikan. Yang perlu menjadi perhatian adalah Kabupaten Nias Barat dan Kabupaten Nias Utara yang sama sekali tidak mengalokasikan ABPD tanpa transfer daerah untuk bidang pendidikan, artinya seluruh anggaran pendidikan di daerah tersebut berasal dari dana transfer. Kemdian Kabupaten Langkat hanya mengalokasikan $0,32 \%$ APBD tanpa trasnfer untuk bidang pendidikan, diikuti Kabupaten Nias Selatan yang hanya mengalokasikan $0,50 \%$. Hal-hal tersebut menunjukkan kurangnya komitmen pemerintah daerah dalam membangun pendidikan padahal pendidikan merupakan komponen penting dalam pembangunan manusia. Sebaliknya APBD lebih berfokus pada kegiatan operasional pemerintahan.

Persentase Angka Melanjutkan SD ke SMP di Sumatera Utara berdasarkan data pada Ikhtisar Data Pendidikan Tahun 2016/2017 adalah sebesar 76,51\%. Rata-rata nasional Persentase Angka Melanjutkan SD ke SMP adalah 78,08\%. Jumlah lulusan SD di Sumatera Utara pada tahun tersebut sejumlah 297.318 orang sementara
SMA/SMK/STM adalah 102,16\%. Pemerintah daerah diharapkan dapat menyediakan sekolahsekolah agar persentase anak-anak yang melanjutkan pendidikan ke jenjang berikutnya semakin baik dan ke depannya tidak ada anak yang tidak dapat melanjutkan pendidikan karena sekolah yang tidak tersedia.

\section{KESIMPULAN DAN SARAN}

\subsection{Kesimpulan}

Kesimpulan yang diperoleh dari penelitian antara lain:

1. Di bidang kesehatan PAD memiliki pengaruh signifikan terhadap Angka Harapan Hidup $(\mathrm{AHH})$. Hal ini dapat terjadi karena daerahdaerah di Sumatera Utara sudah mampu mengelola PAD dengan baik dan menggunakannya untuk sektor kesehatan, seperti sarana dan prasarana kesehatan serta pelayanan publik di bidang kesehatan lainnya. Di bidang pendidikan hasil penelitian menunjukkan PAD memiliki pengaruh signifikan terhadap Harapan Lama Sekolah (HLS). Daerah-daerah di Sumatera Utara mampu mengelola PAD dengan baik dan mampu menyediakan sistem pendidikan yang baik. PAD juga memiliki pengaruh signifikan terhadap Rata-rata Lama Sekolah (RLS) di daerah-daerah se-Sumatera Utara. Hal ini dapat disebabkan oleh daerah yang dapat mengoptimalkan PAD untuk memberikan bantuan biaya pendidikan kepada masyarakat agar bisa terus melanjutkan pendidikannya dan tidak putus sekolah karena himpitan biaya. Di bidang daya beli masyarakat hasil penelitian menunjukkan PAD memiliki pengaruh signifikan terhadap Pengeluaran Per Kapita. Pemerintah daerah dapat mengoptimalkan PAD untuk sektor-sektor yang dapat mendorong pertumbuhan ekonomi di daerah dan peningkatan pendapatan masyarakat, seperti penyediaan

Tabel 4.4 Jumlah Sekolah di Sumatera Utara

\begin{tabular}{cccc}
\hline Tahun & \multicolumn{3}{c}{ Pendidikan } \\
\cline { 2 - 4 } & SD & SMP & SMA \\
\hline 2013 & 9.432 & 2.357 & 868 \\
2014 & 9.502 & 2.406 & 1.029 \\
2015 & 9.524 & 2.424 & 1.029 \\
2016 & 9.528 & 2.419 & 1.016 \\
2017 & 9.649 & 2.525 & 1.064 \\
\hline
\end{tabular}

Sumber: Badan Pusat Statistik Provinsi Sumatera Utara (2018)

jumlah murid SMP baru berjumlah 227.480 orang.

Persentase Angka Melanjutkan SMP ke SMA/SMK/STM di Sumatera Utara adalah 109,19\%, yaitu lulusan SMP berjumlah 210.676 orang sedangkan jumlah siswa SMA/SMK/STM baru adalah 230.038. Rata-rata nasional Persentase Angka Melanjutkan SMP ke lapangan kerja, industri padat karya, mendorong investasi masuk ke daerah, dan pengembangan pariwisata.

2. DAU tidak memiliki pengaruh signifikan terhadap bidang kesehatan, pendidikan, dan daya beli masyarakat. Faktor utama 
penyebabnya adalah penggunaan DAU yang tidak tepat sasaran. Kebanyakan daerah menggunakan DAU untuk keperluan belanja operasional, belanja gaji pegawai, dan urusan pemerintahan lainnya. Sebaliknya pemerintah daerah kurang memperhatikan pelayanan publik di bidang kesehatan dan pendidikan yang lebih dibutuhkan masyarakat. Menurut Bank Indonesia dalam Kajian Ekonomi dan Keuangan Regional Provinsi Sumatera Utara terdapat ketimpangan yang mencolok di dalam alokasi belanja pada APBD. Pada tahun 2017 anggaran belanja operasi sebesar 78\% berbanding dengan anggaran belanja modal yang sebesar $21 \%$ dan sisanya untuk kelompok belanja lain. Hal yang sama juga terlihat pada tahun 2018, anggaran belanja operasi sebesar $79,09 \%$ berbanding dengan anggaran belanja modal yang sebesar 20,74\% kemudian diikuti alokasi belanja lain. Proporsi yang timpang ini menunjukkan komitmen pemerintah yang kurang dalam memberikan pelayanan kepada masyarakat. Belanja operasi hanya berfokus pada kebutuhan PNS daerah dan perangkat pemerintah lainnya, seperti keperluan gaji, tunjangan, dan honorarium. Sebaliknya alokasi belanja modal dibutuhkan untuk membangun sarana dan prasarana pelayanan kepada masyarkat. DAU tidak digunakan tepat sasaran dan tidak sesuai dengan tujuan utamanya lagi. Anggaran yang berfokus pada belanja operasi hanya dapat dinikmati sebagian pihak.

3. DAK Fisik tidak memiliki pengaruh signifikan terhadap bidang kesehatan, pendidikan, dan standar hidup. Peyebabnya ada dari sisi pemerintah daerah, pemerintah pusat, dan kementerian/lembaga sendiri. Dari sisi pemerintah daerah penyebabnya adalah kurangnya komitmen pemerintah daerah. Pelaksanaan DAK FISIK yang tidak maksimal berdampak pada rendahnya penyerapan anggaran DAK Fisik. Selain itu perencanaan yang kurang matang membuat pemerintah daerah melakukan perubahan rencana kegiatan. Proses perubahan rencana tersebut cukup panjang karena harus melibatkan Dewan Perwakilan Rakyat Daerah (DPRD) dan persetujuan dari pemerintah pusat. Proses yang panjang tersebut membuat pelaksanaan DAK Fisik berpotensi terlambat dan tidak selesai tepat waktu. Dari sisi pemerintah pusat faktor penyebabnya adalah ketidakpastian pemerintah pusat dalam memberikan informasi besaran alokasi DAK Fisik di tahun berikutnya. Hal ini membuat pemerintah daerah kesulitan dalam melakukan perencanaan kegiatan Ketidakpastian besaran alokasi DAK Fisik dapat disebabkan oleh anggaran belanja dan transfer pemerintah pusat yang bergantung pada realisasi penerimaan di tahun berjalan. Dari sisi kementerian/lembaga faktor penyebabnya adalah kementerian/lembaga yang terlambat menerbitkan petunjuk teknis pelaksanaan dan penyaluran DAK Fisik. Terlambatnya petunjuk teknis terbit membuat pemerintah daerah penerima DAK Fisik kesulitan untuk mengeksekusi dana tersebut. Faktor lain yang menyebabkan pengaruh DAK Fisik tidak signifikan terhadap pembangunan manusia di daerah adalah permasalahan lelang, mulai dari gagal lelang, proses lelang yang terlambat, hingga rekanan lelang yang jauh dari lokasi daerah penerima DAK Fisik. Permasalahan lelang membuat pelaksanaan kegiatan DAK Fisik menjadi terlambat, output yang dihasilkan tidak dapat langsung digunakan, dan kerap membuat penyerapannya tidak maksimal.

\subsection{Saran}

Saran yang diperoleh dari penelitian antara lain:

1. Di bidang kesehatan pemerintah diharapkan dapat lebih baik lagi menggunakan PAD, DAU, dan DAK Fisik untuk peningkatan fasilitas dan layanan kesehatan kepada publik. Selain itu jumlah tenaga medis beserta kualitas tenaga medis harus ditingkatkan untuk dapat memberikan pelayanan yang baik kepada masyarakat. Keberadaan fasilitas dan layanan kesehatan juga harus bisa diakses dengan mudah oleh masyarakat, jangan hanya terpusat di daerah-daerah tertentu saja. Pemerintah daerah juga perlu memberikan perhatian lebih kepada daerah masih memiliki Angka Harapan Hidup yang rendah. Percepatan program-program kesehatan dan peningkatan fasilitas kesehatan harus diberikan lebih kepada daerah tersebut.

2. Di bidang pendidikan PAD, DAU, dan DAK Fisik diharapkan dapat digunakan optimal untuk meningkatkan aksesibilitas masyarakat dalam memperoleh sarana dan prasarana pendidikan. Fasilitas pendidikan yang diberikan pemerintah harus memadai. Selain itu pemerintah juga dapat menggunakan PAD, DAU, dan DAK Fisik untuk membantu masyarakat dalam membiayai pendidikan, seperti BOS (Belanja Operasional Sekolah), BAUSKM (Bantuan Anak Usia Sekolah Keluarga Miskin), dan beasiswa, agar orangorang yang sudah menempuh pendidikan tidak putus sekolah. Apabila pemerintah dapat memaksimalkan pengelolaan dana tersebut maka tingkat partisipasi masyarakat bersekolah akan tinggi dan jumlah masyarakat yang memiliki bekal pendidikan baik akan bertambah banyak. Daerah yang 
memiliki nilai Harapan Lama Sekolah rendah perlu mendapat perhatian lebih dari pemerintah daerah. Percepatan pembangunan sarana dan prasarana pendidikan harus lebih giat dilakukan agar masyarakat di daerah tersebut mendapatkan akses ke pendidikan dengan mudah dan meningkatkan nilai Harapan Lama Sekolah. Sejalan dengan Harapan Lama Sekolah, pemerintah daerah juga harus memberikan perhatian lebih kepada daerah yang memiliki nilai Rata-rata Lama Sekolah terendah di Sumatera Utara. Perbedaan nilai Rata-rata Lama Sekolah yang sangat jauh antardaerah menjadi sinyal bahwa pemerataan pendidikan belum dilakukan dengan baik.

3. Di bidang standar hidup atau pengeluaran per kapita pemerintah diharapkan dapat menggunakan PAD, DAU, dan DAK Fisik untuk menjalankan program yang dapat mendorong perekonomian dan meningkatkan pendapatan masyarakat. Program pembangunan tersebut dapat berupa penyediaan lapangan kerja, bantuan serta dukungan kepada industri padat karya dan usaha mikro kecil dan menengah. Selain itu potensi-potensi masingmasing daerah, seperti pariwisata, perdagangan, dan ekspor, harus didukung dengan penggunaan dana-dana PAD, DAU, dan DAK Fisik dengan tepat. Pengelolaan dana yang tepat sasaran pada sektor-sektor yang menjadi potensi daerah akan mampu menciptakan lapangan kerja baru. Dengan banyaknya lapangan kerja baru maka pendapatan masyarakat dapat meningkat yang berdampak pada meningkatnya daya beli masyarakat. Misalnya program yang cocok untuk daerah-daerah yang potensinya adalah keindahan alam yang baik antara lain pengembangan sektor pariwisata, mulai dari penyediaan infrastruktur, penataan tempattempat wisata, hingga pelatihan pariwisata dan hospitality kepada masyarakat. Penyediaan lapangan kerja baru dan penyerapan tenaga kerja akan bertambah apabila sektor pariwisata diperhatikan dengan baik.

4. Berkaitan dengan tata kelola PAD, DAU, dan DAK Fisik, pengelolaan dan penggunaan danadana tersebut harus tepat sasaran. Programprogram yang dibuat dan dibiayai dari danadana tersebut juga harus merupakan program yang tepat guna. Penggunaan PAD dan DAU sebaiknya tidak digunakan dengan berfokus pada pembiayaan belanja gaji pegawai dan urusan pemerintahan saja, namun digunakan untuk kepentingan pelayanan publik di bidang pendidikan atau kesehatan yang manfaatnya dapat langsung dirasakan.
Anggaran di bidang kesehatan dan pendidikan harus ditingkatkan agar pembangunan berbagai sarana dan prasarana di bidang kesehatan dan pendidikan dapat berjalan dengan baik. Dengan alokasi anggaran yang memadai diharapkan pemerintah daerah dapat menambah jumlah sekolah, puskesmas, hingga rumah sakit. Dengan demikian maka nilai Angka Harapan Hidup, Harapan Lama Sekolah, dan Rata-rata Lama Sekolah di kabupaten/kota di Sumatera Utara bisa meningkat lebih baik.

5. Berkaitan dengan tata kelola DAK Fisik, pemerintah daerah diharapkan memiliki komitmen yang tinggi dalam melaksanakan kegiatan yang bersumber dari DAK Fisik. Komitmen tersebut dimulai dari perencanaan yang matang sehingga tidak perlu melakukan perubahan rencana kegiatan di tahun berjalan. Kemudian pelaksanaan kegiatan dilakukan tepat waktu agar output kegiatan dapat digunakan masyarakat, tidak terlambat melakukan lelang kegiatan, hingga pertanggungjawaban penggunaan DAK Fisik yang baik. Pemerintah pusat juga diharapkan dapat memberikan informasi kepada pemerintah daerah tentang kepastian anggaran DAK Fisik di tahun berikutnya. Dengan kepastian tersebut pemerintah daerah dapat melakukan perencanaan kegiatan yang baik. Selain itu, kementerian/lembaga teknis diharapkan tidak terlambat mengeluarkan petunjuk teknis pelaksanaan penyaluran DAK Fisik agar pihak-pihak yang menerima DAK Fisik tidak terhambat melaksanakan kegiatan.

6. Meningkatkan kontrol dan pengawasan dalam penggunaan DAU dan DAK Fisik. Dengan kontrol yang baik maka penggunaan DAU akan menjadi tepat sasaran dan berfokus pada pelayanan publik, tidak hanya untuk membiayai belanja gaji pegawai dan urusan pemerintahan saja. Kontrol yang baik terhadap penggunaan DAK Fisik dapat membuat anggaran DAK Fisik terserap dengan baik. Selain itu output dari pembangunan yang berasal dari DAK Fisik dapat langsung terasa dan berdampak bagi masyarakat.

7. Memperbanyak jumlah time series di dalam penelitian selanjutnya agar hasil penelitian yang diperoleh semakin akurat dan mencerminkan keadaan di lapangan. 


\section{IMPLIKASI DAN KETERBATASAN}

Penelitian ini diharapkan dapat memberikan informasi kepada pemerintah daerah dan masyarakat tentang fakta pengelolaan PAD, DAU, dan DAK Fisik dalam upaya peningkatan pembangunan manusia serta menjadi bahan pertimbangan bagi pemerintah daerah dalam mengambil kebijakan terkait pelaksanaan desentralisasi, dana perimbangan, dan terciptanya pembangunan manusia yang baik. Selain itu penelitian ini juga dapat menjadi referensi dan sumber informasi akademis untuk penelitianpenelitian selanjutnya.

Keterbatasan yang ada di dalam penelitian ini antara lain:

1. Di tengah banyaknya faktor yang mempengaruhi Indeks Pembangunan Manusia (IPM), variabel independen yang digunakan di dalam penelitian hanya tiga, yaitu Pendapatan Asli Daerah (PAD), Dana Alokasi Umum (DAU), dan Dana Alokasi Khusus (DAK) Fisik.

2. Jumlah times series yang digunakan di dalam penelitan hanya tiga tahun, yaitu dari tahun 2016 hingga 2018.

\section{REFERENSI}

Alkadri, M., \& Suhandojo. (2001). Tiga pilar pengembangan wilayah: sumber daya alam, sumber daya manusia, dan teknologi. Jakarta: Pusat Pengkajian Kebijakan Teknologi Pengembangan Wilayah BPPT.

Asmita, Fitrawaty, \& Ruslan, D. (2017). Analysis of factors affecting the human development index in north sumatra province. IOSR Journal of Business and Management (IOSR-JBM), Volume 19 Issue 10 Version VII, 27-36.

Astri, M., Nikensari, S. I., \& Kuncara, W. H. (2013). Pengaruh pengeluaran pemerintah daerah pada sektor pendidikan dan kesehatan terhadap indeks pembangunan manusia di indonesia. Jurnal Pendidikan Ekonomi dan Bisnis, Volume 1 Nomor 1, 77-102.

Badan Pusat Statistik. (2016). Indeks pembangunan manusia 2015. Jakarta: Badan Pusat Statistik.

Badan Pusat Statistik. (2017). Indeks pembangunan manusia 2016. Jakarta: Badan Pusat Statistik.

Badan Pusat Statistik. (2018). Indeks pembangunan manusia 2017. Jakarta: Badan Pusat Statistik.
Badan Pusat Statistik. (2019). Indeks pembangunan manusia 2018. Jakarta: Badan Pusat Statistik.

Bank Indonesia. (2017). Kajian ekonomi dan keuangan regional Provinsi Sumatera Utara. Medan: Bank Indonesia.

Bank Indonesia. (2018). Kajian ekonomi dan keuangan regional Provinsi Sumatera Utara. Medan: Bank Indonesia.

Bank Indonesia. (2019). Kajian ekonomi dan keuangan regional Provinsi Sumatera Utara. Medan: Bank Indonesia.

Chakraborty, S. (2002). Endogenous lifetime and economic growth. Portland: University of Oregon.

Cohen, J. M., \& Peterson, S. B. (1999). Administrative decentralization: strategies for developing countries. Connecticut: Kumahan Press.

Darise, N. (2009). Pengelolaan keuangan daerah. Jakarta: Indeks.

Dinas Kesehatan Provinsi Sumatera Utara. (2018). Profil kesehatan Provinsi Sumatera Utara. Medan: Dinas Kesehatan Provinsi Sumatera Utara.

Gujarati, D. N. (2012). Dasar-dasar ekonometrika. Jakarta: Salemba Empat.

Halim, A. (2004). Pendapatan asli daerah. Jakarta : Salemba Empat.

Haq, M. U. (1999). Reflections on human development. Delhi: Oxford University Press.

Harahap, Riva U. (2017). Pengaruh dana alokasi umum (dau), dana alokasi khusus (dak) dan dana bagi hasil (dbh) terhadap indeks pembangunan manusia (ipm) pada kabupaten/kota di Sumatera Utara. KITABAH, Volume 1 Nomor 1 Januari - Juni 2017, 118-130.

Indarti, S. H. (2017). Pembangunan Indonesia dalam pandangan amartya sen. IJPA-The Indonesian Journal of Public Administration, Volume 3 Nomor 1, 35-50.

Indraningrum, T. (2011). Pengaruh pendapatan asli daerah (pad) dan dana alokasi umum (dau) terhadap belanja langsung (studi pada pemerintah daerah kabupaten/kota di Provinsi Jawa Tengah). Skripsi Fakultas Ekonomi dan Bisnis Universitas Diponogoro.

Kahang, M., Saleh, M., \& Suharto, R. B. (2016). Pengaruh pengeluaran pemerintah sektor pendidikan dan keseheatan terhadap 
indeks pembangunan manusia di Kabupaten Kutai Timur. Jurnal Ekonomi, Manajemen dan Akuntansi, Volume 18(2), 130-140.

Kementerian Kesehatan Republik Indonesia. (2018). Data dan informasi profil kesehatan Indonesia 2017. Jakarta: Kementerian Kesehatan.

Kuncoro, M. (2010). Dasar-dasar ekonomi pembangunan. Yogyakarta: UPP.

Kuncoro, M. (2010). Masalah, kebijakan, politik: ekonomika pembangunan. Jakarta: Erlangga.

Latuconsina, Z. M. (2016). analisis faktor-faktor yang mempengaruhi indeks pembangunan manusia kabupaten malang berbasis pendekatan perwilayahan dan regresi panel. Journal of Regional and Rural Development Planning, 202-216.

Lugastoro, Pitron, D., \& Ananda, C. F. (2013). Analisis pengaruh pad dan dana perimbangan terhadap indeks pembangunan manusia kabupaten/kota di Jawa Timur. Jurnal Ilmiah Fakultas Ilmu Ekonomi dan Bisnis Universitas Brawijaya, 1-19.

Mahmudi. (2010). Manajemen keuangan daerah. Jakarta: Erlangga.

Mangkoesoebroto. (1993). Ekonomi publik. Edisi III. Yogyakarta: BPFE UGM.

Mardiasmo. (2008). Otonomi dan Manajemen Keuangan Daerah. Jakarta: Penerbit Andi.

Maulana. (2016). Factors affecting the human development index in Musi Rawas Regency South Sumatera Province. Proceedings of Academics World 28th International Conference, 77-82.

Mirza, D. S. (2012). Pengaruh kemiskinan, pertumbuhan ekonomi, dan belanja modal terhadap indeks pembangunan manusia di jawa tengah tahun 2006 2009. Economics Development Analysis Journal EDAJ 1, 102-113.

Nachrowi, D. \& Usman, H. (2006). Penggunaan teknik ekonometrika. Jakarta: PT Raja Grafindo Persada.

Paulson, J. (2011). Education, conflict, and development. Oxford: Symposium Books.

Putra, P. G., \& Ulupui, I. G. (2015). Pendapatan asli daerah, dana alokasi umum, dana alokasi khusus untuk meningkatkan indeks pembangunan manusia. E-Jurnal
Akuntansi Universitas Udayana, 11.3, 863877.

Rahardja, P., \& Manurung, M. (2005). Teori ekonomi makro: suatu pengantar. Jakarta: LP FEUI.

Ramirez, A., Ranis, G., \& Stewart, F. 1997. Economic growth and human. development. Center Discussion Paper, (787), 1-21.

Republik Indonesia. (2003). Undang Undang Nomor 20 Tahun 2003 tentang Pendidikan Nasional.

Republik Indonesia. (2003). Undang-undang Nomor 17 Tahun 2003 tentang Keuangan Negara.

Republik Indonesia. (2004). Undang-undang Nomor 1 Tahun 2004 tentang Perbendaharaan Negara.

Republik Indonesia. (2004). Undang-undang Nomor 32 Tahun 2004 tentang Pemerintah Daerah.

Republik Indonesia. (2004). Undang-undang Nomor 33 Tahun 2004 tentang Perimbangan Keuangan antara Pemerintah Pusat dan Pemerintah Daerah.

Republik Indonesia. (2009). Undang-undang Nomor 28 Tahun 2009 tentang Pajak Daerah dan Retribusi Daerah.

Republik Indonesia. (2014). Peraturan Presiden Republik Indonesia Nomor 162 Tahun 2014 tentang Rincian APBN TA 2015.

Republik Indonesia. (2015). Peraturan Presiden Republik Indonesia Nomor 137 Tahun 2015 tentang Rincian APBN TA 2016.

Republik Indonesia. (2016). Peraturan Presiden Republik Indonesia Nomor 97 Tahun 2016 Tentang Rincian APBN TA 2017.

Republik Indonesia. (2017). Peraturan Presiden Republik Indonesia Nomor 107 Tahun 2017 tentang Rincian Anggaran Pendapatan dan Belanja Negara Tahun Anggaran 2018.

Rosadi, D. (2011). Analisis ekonometrika dan runtun waktu terapan dengan eviews. Yogyakarta: Andi Offset.

Schultz, T. W. (1972). Human resources (human capital: policy issues and research opportunities). New York: National Bureau of Economic Research.

Sen, A. (1985). Commodities and capabilities. Netherland: Elsevier Science Publisher. 
Sen, A. (1999). Development as freedom. New York: Anchor Books.

Stanley. (1993). Human capital: a theoretical and empirical analysis. London: The University of Chicago Press, Ltd.

Sukirno, S. (2015). Makroekonomi: teori pengantar. Jakarta: Raja Grafindo Persada.

Tjiptoherijanto, P. (1986). Hubungan pembangunan kesehatan dengan peningkatan pertumbuhan ekonomi. EKI, Volume XXXIV Nomor 1, 121-131.

Todaro, M. D. (2006). Pembangunan ekonomi. Jakarta: Erlangga.

UNDP. (1996). Human development report 1995. New York: Oxford University Press.

UNDP. (2001). Human development report 2000. New York: Oxford University Press.

WHO. (2002). Global status report. Geneva: World Health Organization.

World Bank. (2000). Human Development Index. New York: Oxford University Press.

Yolanda, Y. (2017). Analysis of factors affecting inflation and its impact on human development index and poverty in indonesia. European Research Studies Journal, Volume XX, Issue 4B, 38-56. 